\title{
Transformation of the Ecological-economic System of the Coal Mining Region
}

\author{
Mikhailov Vladimir G. ${ }^{\mathrm{a}}$, Golofastova Natalya N. ${ }^{\mathrm{b}}$, Seredyuk Ilya V. ${ }^{\mathrm{c}}$ \\ T. F. Gorbachev Kuzbass State Technical University \\ Kemerovo, Russian Federation \\ ae-mail: mvg.eohp@kuzstu.ru, ${ }^{\mathrm{b} e}$-mail: gnn.eomp@kuzstu.ru, ${ }^{\mathrm{c}}$ e-mail: ilsersiv@mail.ru
}

\begin{abstract}
The evolution and the origin of known systemic ecological-economic interactions, which is especially important in the modern conditions of "technocratic" mode of production characteristic of the coal industry of Kuzbass, are examined in the article. The purpose of the research is to establish the transformation laws of ecological-economic system of the coalmining region and to identify the factors affecting the efficiency of its management and the improvement of socio-economic and environmental indicators. The process of formation of ecologicaleconomic systems differentiated by economic, climatic, spatial and other criteria with definition of obligatory, systematically important elements, is studied. A study of modified ecologicaleconomic systems under the influence of the specific environment requirements, including those socio-economic, ecological, anthropological ecosystems and species directly related to the development of the infrastructure industries, which include coal mining, is carried out. The main result of the study is to develop proposals to improve the functioning of the regional ecologicaleconomic system of the coal-mining region. The practical significance of the research is modeling the effective ecologicaleconomic system of the coal-mining region adapted to the external economic and environmental challenges.
\end{abstract}

Keywords - coal industry, ecological-economic systems, indicators of negative impact on the environment, environmental safety, modification of environmental systems.

\section{INTRODUCTION}

The Kemerovo region as a coal-mining region has a high share of mining in gross regional product [1] (Fig. 1).

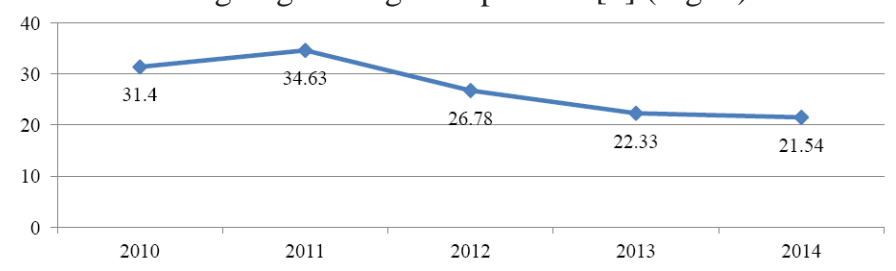

Fig. 1. The share of mineral production in the gross regional product of the Kemerovo region, $\%$

Figure 1 shows that the share of mining in the gross regional product of the Kemerovo region has changed from $34.63 \%$ in 2011 to $21.54 \%$ in 2014 , the coal industry being still the most systematically important element of the regional economy.

An adequate understanding of the need to study the ecological-economic system of the coal-mining region is also connected with the main environmental indicators of the negative impact on the environment (Table 1).

TABLE 1. The dynamics of indicators of the negative impact of fuel and energy mineral extraction enterprises of the Kemerovo region [2, 3]

\begin{tabular}{|l|c|c|c|c|c|}
\hline \multicolumn{1}{|c|}{ Indicator } & 2010 & 2011 & 2012 & 2013 & 2014 \\
\hline $\begin{array}{l}\text { Coal production } \\
\text { volume, million tons }\end{array}$ & 186 & 192 & 201 & 203 & 209 \\
\hline $\begin{array}{l}\text { Emissions from } \\
\text { stationary sources } \\
\text { into the air, thousand } \\
\text { tons }\end{array}$ & 826.959 & 804.266 & 785.998 & 840.853 & 807.057 \\
\hline $\begin{array}{l}\text { Specific emissions of } \\
\text { pollutants from } \\
\text { stationary sources } \\
\text { into the air, } \mathrm{t} / \mathrm{t}\end{array}$ & 0.004 & 0.004 & 0.004 & 0.004 & 0.004 \\
\hline $\begin{array}{l}\text { Wastewater } \\
\text { discharge, million } \mathrm{m}^{3}\end{array}$ & 192.820 & 189.460 & 199.75 & 221.216 & 208.794 \\
\hline $\begin{array}{l}\text { Specific wastewater } \\
\text { discharge, } \mathrm{m}^{3} / \mathrm{t}\end{array}$ & 1.037 & 1.002 & 0.989 & 1.101 & 0.999 \\
\hline $\begin{array}{l}\text { Production and } \\
\text { consumption waste, } \\
\text { million tons }\end{array}$ & 1789.9 & 2422.3 & 2613.0 & 2644.1 & 2622.9 \\
\hline $\begin{array}{l}\text { Specific production } \\
\text { and consumption } \\
\text { waste, } \mathrm{t} / \mathrm{t}\end{array}$ & 9.623 & 12.816 & 12.936 & 13.155 & 12.550 \\
\hline
\end{tabular}

Table 1 shows that the Kuzbass coal industry is developing dynamically, increasing the volume of coal production. A significant level of impact on the environment should be noted, in particular, the specific impact indicators remain high, and for example, in 2013 the specific wastewater discharge amounted to $1.101 \mathrm{~m}^{3} / \mathrm{t}$, and the specific production and consumption waste $-13.155 \mathrm{t} / \mathrm{m}$. A similar trend continued in 2014.

Due to the fact that the coal industry is infrastructural and defines the sustainable development of the Kemerovo region, it is appropriate to consider the region as a single ecologicaleconomic system $[4,5,6]$.

The purpose of the research is to establish the transformation laws of ecological-economic system of the coal mining region and to identify factors affecting the efficiency 
of its management and the improvement of socio-economic and environmental indicators.

Scientific novelty of the results of the work is represented by the clarification and the development of the theoretical and methodological foundations of the study of the process of transformation of ecological-economic systems of the coalmining region enhancing the understanding of the content and management specifics of the resource extraction areas, taking into account their environmental capacity.

The developed proposals may be used to model the effective ecological-economic system of the coal-mining region adapted to the external challenges.

\section{SUBJECT OF RESEARCH}

The object of study is the transformation processes of ecological-economic interactions between the industrial plants and the environment. The subject of research is the ecologicaleconomic system of Kemerovo region as a coal-mining region. The study is based on an analysis of the approaches of different authors to the definition of the environmental system, ecological-economic system and their modifications due to the development of the region with intensive coal mining. The elements of system analysis and the results obtained by the specialists in the field of environmental management systems in the coal-mining regions are used in the work.

\section{RESULTS AND DISCUSSIONS}

To understand the process of formation of modern ecological-economic systems of the coal-mining regions it is advisable to consider the emergence of an ecosystem as the initial stage of their formation and development. Gridasov A.Y. notes [7] that the definition of the term "ecological system" was first given by the English ecologist Arthur Tansley in 1935 as "a stable unity of aggregates of different types of organisms and their environment, based on the related nutrition and reproduction."

The current definition given by N.F. Reimers: an ecological system is the information developing, thermodynamically open set of biotic, environmental components and abiotic sources of matter and energy, the unique and functional link of which in the limits of the time and space typical for a certain area of the biosphere (including the biosphere as a whole) ensures in this area an excess of the internal regular motion of the matter, the energy and the information over the outside exchange (including between the similar aggregates) and thereupon the indefinitely prolonged self-regulation and the development of the entire under the directing influence of biotic and biogenic components [8].

It should be noted that the important property of the natural system is hierarchy. The biosphere which includes the regional ecosystems dividing into local ecosystems is marked out in the ecosystem hierarchy. The highest hierarchical level in the geosystem hierarchy is represented by the geographical shell divided into continental and oceanic geosystems, time zones, physical and geographical countries, regions, provinces, landscapes. The existence of each hierarchical level is determined by the influence of specific factors, for example, the natural selection plays a leading role in biological systems at the population level, interaction with the environment - at biogeocenotic level. Such factors as the steepness and the exposure of the slopes that have a special significance for the operation of coal mines, the height above sea level, the composition of the parent rocks, etc. $[9,10]$ are to be in the foreground in the local ecosystems.

Some authors [11] stress that ecosystem research suggests a differentiation of the rate of the environment change, taking into account the geographical location and level of economic development of the territory. On this basis, we can distinguish areas with different degrees of tense of the environmental situation, which depends on the level of the negative impact on the environment and other parameters. For example, [12] areas in which environmental problems have no place dominate in localities of the 1 st, 2 nd and 3 rd grades. The areas with moderately acute environmental situations dominate in localities of the 4th and 5th grades, although the proportion of areas with acute environmental situations significantly increases for the areas of the 5 th grade. The localities in the 6th rank are characterized by equal ratio of areas with severely and moderately acute environmental situations. The areas with acute ecological situations dominate in localities of the 7 th rank [13]. The Kemerovo region has a high rate of industry development including coal mining, hence, according to many parameters can be attributed to the zone of ecological emergency that actualizes the study of ecological-economic interactions at the regional level.

Considering the process of "inception" of ecologicaleconomic systems, academician M.Y. Lemeshev in 1976 defined the ecological-economic system as "the integration of the economy and the nature represented by the interrelated and interdependent functioning of social production and the flow of natural processes in nature and biosphere in particular." The functions and structure of such a system are defined by the basic set of its constituent elements: nature, people, society and production, assuming a global level.

Thereby any local ecological-economic system inevitably produces conflict with the natural environment, as each company pursues its goal, not taking into account the environmental criteria and the interests of the system as a whole. The coherent evolution of the ecological-economic system, according to Lipenkov A.D., is possible only if there is the regional level control system managing this evolution carried out as a result of the joint solution of a large number of target control tasks, including [14]:

- The optimization of the technological process, which is usually reduced to solving one of the problems of optimum control.

- Change-over to the new technology. Ii is implemented as a result of selecting one of the alternatives aimed at the improvement of the production process in a particular company.

- The development of investment projects to finance the specific activities.

- The distribution of limited region's budget resources, including the municipality, which includes the industrial 
center, between competing environmental projects in accordance with their economic and environmental performance $[14,15,16,17]$.

Ugolnitsky G.A. suggests applying the concept of the hierarchically controlled dynamic systems to the analysis of ecological-economic systems [18, 19]. In accordance with this concept, the natural (environmental) subsystem is treated as the controlled dynamic system, the "Led" - the direct source of human impact on the environment, and the "Leading" that controls this impact in order to comply with certain environmental requirements, being marked out in the economic (socioeconomic) subsystem. Such a system can be called a hierarchically controlled environmental system.

Nikonova Y.I. [20] notes that the development of ecological-economic system of the constituent territory of the Federation with the developed coal industry must comply with the following basic requirements: mobility of communications while maintaining the target function and the formation of system complexes within the limitations specified. The development of the system involves the selection of progressive rational directions of realization of the target function of the ecological-economic system using a valuation system allowing simulating of the trends of correlations and changes of the variables close to real ones. Three groups of elements can be marked out as the main components of the ecological complex of ecological-economic systems: anthropological, conservational, the environmental capacity of the natural environment. The anthropological elements of the environmental complex of the ecological-economic system are those acting at the time of production evaluation and negatively affecting the environment. The conservational group of elements includes all kinds of economic activities aimed at reducing and eliminating the negative impact on the environment, conservation, improvement and rational use of natural-resource potential, as well as all the construction of recreation zones. The environmental capacity includes the comprehensive assessment of the area: social, natural, resource and raw materials, economic, organizational, technological and environmental components.

In the 70 s of the last century, researchers began to use the concept of "ecological-economic system of the region", thereby realizing the ecological-economic approach in determining the prospects for the economic development of the region. In the 90 s of the 20-th century an integrated approach to the concept of "region" was reflected in the scientific literature and a new term "socio-ecologicaleconomic system of the region" was introduced. It is a harmonious combination of subsystems and elements of the region's economy, focused on the local area where an effective solution to the socio-economic problems is provided and a favorable environment life of the population is created on the basis of their development and operation management. The role of the coal mining industry in the process of interaction between the environment and the economy can be determined from the system perspective, considering it as a part of regional environmental and economic system [21, 22].
The works of scientists Akimova T.A., Vorontsova A.P., Gubaidullina T.N., Gurman V.I., Litovka O.P., Nesterov P.M., Nesterov A.P., Novoselov A.L., Ryumina E.V., Chepurnykh N.V. are dedicated to the study of regional ecologicaleconomic systems (territorial level) [23, 24, 25].

Further evolutionary transformation of ecologicaleconomic systems is associated with the definition of the concept of "the socio-ecological-economic system", in which many authors identify three components: nature, economy and society, which can be represented by the corresponding matrix.

Some experts examine ecological-economic systems of coal-mining regions from the perspective of sustainable development theory, identifying the importance of the social component, which depends on the state of health of the economically active population. In particular, the team of authors of the Siberian Branch of the Russian Academy of Sciences formulates the concept of medical-ecologicaleconomic system [26], an important part in assessing the condition and prediction of which is assigned to the development and analysis of mathematical models describing the dynamics and the interaction of these blocks. This is particularly important due to the fact that the main goals and objectives of the region's policy should be to stabilize production and economic growth, including the following subgoals:

- economic structure transformation and the population welfare increase;

- living conditions improvement and the rational use of natural resources;

- public health conservation and improvement.

As noted above, the regions with the overdeveloped industry require specific studies of ecological-economic systems that take into account the role of industrial infrastructure. Therefore, the ecological-economic system of coal-mining region should be considered as an open system and the limits between the system and the external environment should be established. Another important aspect of the effective functioning of ecological-economic system is the information support of the management process (Fig. 2) [27, 28, 29, 30].

A number of studies emphasize the value of the technological component in the ecosystem, which is typical for such a capital-intensive industry like coal mining. For example, E.P. Volynkina defines the concept of technoecosystem [31], which can be defined as a spatially defined set of industrial components which are production sites, shops, businesses, etc. and living organisms, united by a common medium of existence. The techno-ecosystem is any location, since the human industrial activity is carried out in its territory. The manufacturing processes, which are the source of waste generation, as well as their neutralization processes are carried out within the techno-ecosystem. Such a modification of environmental and ecological-economic system is of particular importance for the coal mining industry, generating the large amounts of waste (stripping, host rocks, etc.). In the techno-ecosystems as natural 
ecosystems, material and energy flows are transported between the components and to the environment and there is a system of information links between them.

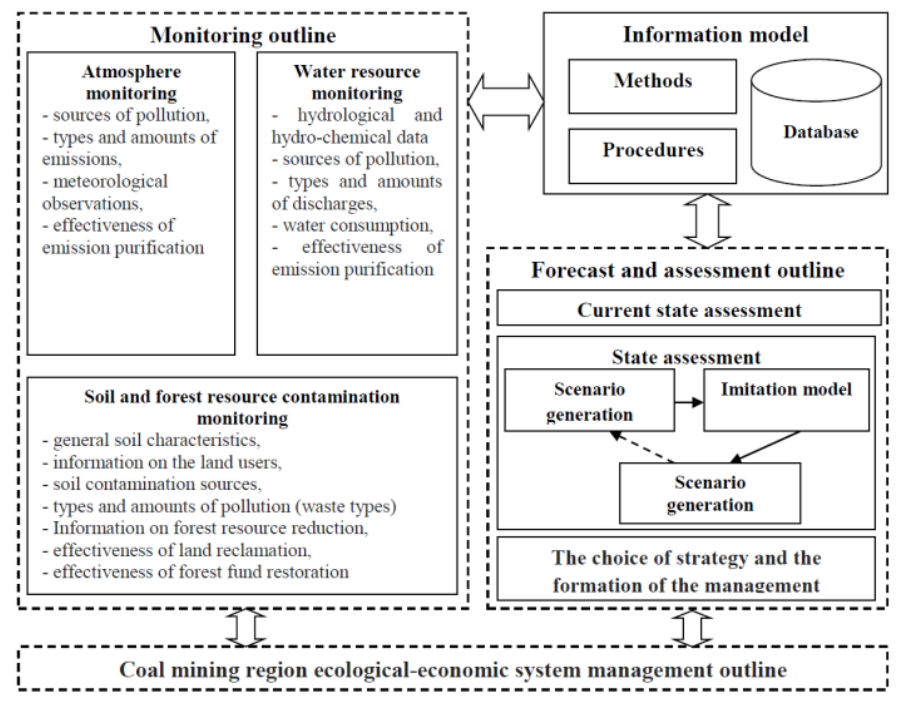

Fig. 2/- Scheme of the information support of ecologicaleconomic system management process in the coal mining region

The difference of the techno-ecosystem modeled from the natural ecosystems is the lack of information flows between its components and the environment, regulating material and energy exchange between them to ensure the closure of the cycle of natural resources and the preservation of stable dynamic equilibrium of the biosphere. The low level of information in techno-ecosystems leads to low level of their organization and, accordingly, the high level of the transported material and energy flows. The basic principles of mining region techno-ecosystems can be summarized as follows:

- the management of material and energy flows between the techno-ecosystem components and the environment should be organized in such a way that the amount of transported materials and energy, and, consequently, the amount of waste generated, should decline, approaching the minimum necessary for each process;

- a minimum amount of waste generated as the result of the manufacturing process is recycled within its technoecosystem ensuring its maximum isolation, or failing that, in neighboring techno-ecosystems, including their material and energy cycle in the biosphere;

- the waste disposed from the techno-ecosystem must be translated into the form that is usual for these ecosystems before its displacement into the natural ecosystems;

- the techno-ecosystem waste disposal in natural ecosystems must be organized in such a way so as not to disturb the existing dynamic equilibrium of ecosystems [32, $33,34,35,36]$.

Implementation of these principles will ensure not only the stability of the biosphere, but also will contribute to the sustainable development of the techno-ecosystems themselves, ensuring the minimization of material, energy, and hence the financial resources. The international practice of waste management hierarchy used within the framework of this approach can be considered as a model of the technoecosystem organization by analogy with the natural ecosystems. The scheme of the formation and evolution of the ecological-economic system of the coal region was developed on the basis of the study (Fig. 3).

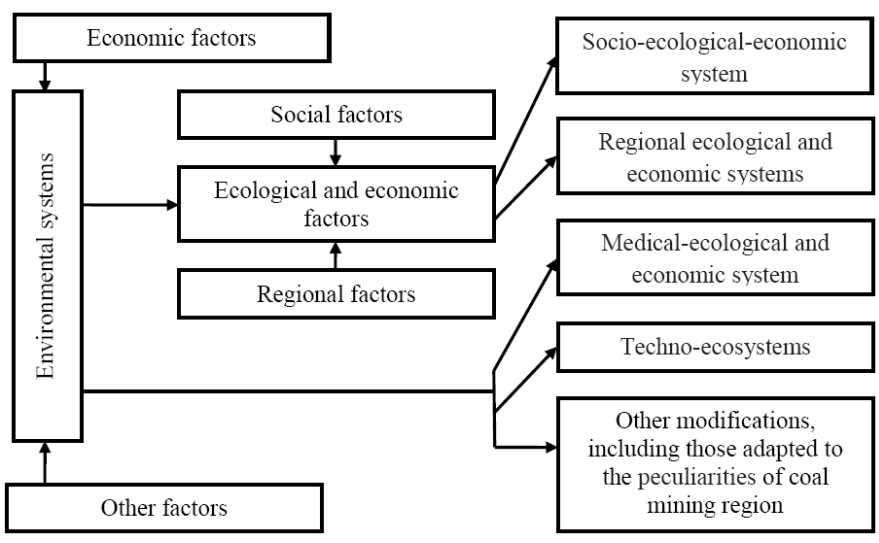

Fig. 3. Scheme of the formation and evolution of ecological-economic system of the coal mining region

Figure 3 shows that the development of the environmental and ecological-economic system of the coal mining region is affected by a number of factors that shape the modifications of these systems, adapted to the peculiarities of territorial entities.

\section{CONCLUSION}

A study of the genesis and evolution of the well-known ecological-economic interactions especially important for the coal-mining region in present-day conditions of the "technocratic" mode of production was carried out in the work, including:

- the level of the impact of the coal mining industry on the formation of the main ecological-economic system indicators was investigated, including the percentage in the gross regional product and in the total value of the negative impact on the environment, including per 1 ton of coal mined;

- the process of formation and development of contemporary environmental and ecological-economic systems, differentiated by economic, climatic, spatial and other criteria was studied, the most important infrastructure elements were identified;

- the study of the modified ecological-economic systems under the influence of the specific effects of the environment (socio-ecological-economic systems, medical-ecological economic systems, techno-ecosystems, water industry and other species) directly related to the development of infrastructure sectors of the economy and industry in the region has been conducted;

- the algorithm for the information support of ecologicaleconomic system of the region's coal mining management process was refined; 
- the scheme of formation and evolution of ecologicaleconomic systems of coal-mining region was developed;

- the main characteristics of ecological-economic system of the coal mining region, deformed under the influence of high environmental loads, in order to develop an effective management strategy aimed at achieving the optimal environmental and economic parameters were identified.

\section{REFERENCES}

[1] Kemerovostat web portal [Internet-portal Kemerovostata. URL: http://kemerovostat.gks.ru (accessed: 15.04.2016).

[2] Kuzbass v tsifrakh [Kuzbass by numbers]. Shatirov S.V. [and others]. Ugol Kuzbassa [Kuzbass coal]. 2015. No. 5. P. 11.

[3] Report on the status and protection of the environment of the Kemerovo region in 2014 [Doklad o sostoyanii i okhrane okruzhayushchey sredy v Kemerovskoy oblasti v 2014 godu]. URL: http://ecokem.ru (accessed: 15.04.2016).

[4] Burkov V.N., Novikov D.A., Shchepkin A.V. Mekhanizmy upravleniya ekologo-ekonomicheskimi sistemami [Mechanisms of ecological and economic system management]. Moscow, Publisher of physical and mathematical literature, 2008. 244 P.

[5] Pantyukova M.E. Formirovanie mekhanizma upravleniya ekologoekonomicheskimi sistemami [Formation of ecological and economic system management mechanism]. Vestnik Kazanskogo tekhnologicheskogo universiteta [Herald of Kazan Technological University]. 2011. Vol. 17, No. 1. P. 200-202.

[6] Tretyakova E.A. Assessing sustainability of development of ecological and economic systems: a dynamic method. Studies on Russian economic development. 2014. Vol. 25, No. 4. P. 423-430.

[7] Gridasov A.Ju. Sovershenstvovanie upravleniya razvitiem ekologoekonomicheskoy sistemy resursodobyvayushchego regiona [Improvement of the management of the development of ecological and economic system of resource-extraction region: dissertation in support of candidature for an economic degree]. Novosibirsk, 2006. 166 P.

[8] Rejmers N.F. Ekologiya (teorii, zakony, pravila, printsipy I gipotezy) [Ecology (theories, laws, rules, principles and hypotheses)]. Moscow, Young Russia, 1994. 367 P.

[9]Ubugunov L. L., Kulikov A. I. and Kulikov M. A. On the application of risk analysis technology for assessment of the ecological hazard of desertification (by the example of Republic of Buryatia). Contemporary problems of ecology. 2011. Vol. 4. No. 2.

[10] Novoselov A.L., Novoselova I.Ju. Modeli I metodi prinyatiya resheniy v prirodopolzovanii [Models and methods of decision-making in natural resource management]. Moscow, JuNITI-DANA, 2010. 383 P.

[11] Aktualnye problem sotsialno-ekonomicheskogo razvitiya predpriyatiy, otrasley, kompleksov [Actual problems of socio-economic development of enterprises, industries, complexes]. Vol. 2. Kuritsyn A.V. [and others]. Krasnoyarsk, Center for Science and Innovation, 2011.298 P.

[12] Nuzhina I.P., Yudahina O.B. Konceptualnaya model regionalnoy ekologo-ekonomicheskoy sistemy [Conceptual model of the regional ecological-and-economic system]. Vestnik Tomskogo gosudarstvennogo universiteta. Ekonomika [Tomsk State University Journal of Economics]. 2008. No. 1. P. 54-67.

[13] Kovalev V.A., Potapov V.P., Schastlivcev E.L. Monitoring sostoyaniya prirodnoy sredy ugledobyvayushhikh rajonov Kuzbassa [Monitoring of the natural environment state of Kuzbass coal-mining areas]. Novosibirsk, Publisher of Siberian Branch of the Russian Academy of Sciences, 2013. $312 \mathrm{P}$.

[14] Lipenkov A.D. Upravlenie promyshlennym uzlom v ekologoekonomicheskoy sisteme [Management of industrial hub in ecological and economic system: dissertation in support of candidature for an economic degree]. Chelyabinsk, 2000. 160 P.

[15] Shchepkin A.V. Ekologicheskij menedzhment: igrovoe modelirovanie ekonomicheskikh mekhanizmov v ekologii [Environmental management: game modeling of economic instruments in ecology]. Inzhenernaya elologiya [Engineering Ecology]. 1996. No. 6. P 44-50.

[16] Lesin Ju.V., Leshukov T.V. Ekonomicheskie zatraty na prirodookhrannuyu deyatelnost $\mathrm{v}$ Kemerovskoy oblasti [Economic payments for environmental protection in Kemerovo region]. Vestnik kuzbasskogo gosudarstvennogo tehnicheskogo univeristeta [Vestnik of Kuzbass State Technical University]. 2013. No. 4. P. 73-74.

[17] Kiseleva T.V., Mikhailov V.G. Metody otsenki i upravlenie ekologoekonomicheskimi riskami kak mekhanizm obespecheniya ustoychivogorazvitiya ekologo-ekonomicheskoy sistemy [Methods of assessment and management of environmental-economic risks as a tool for sustainable development of environmental-economic system]. Systemy upravleniya i informatsionnye tekhnologii [Control Systems and Information Technology]. 2012. Vol. 48. No 2. P. 69-74.

[18] Ugolnitskiy G.A. Upravlenie ekologo-ekonomicheskimi sistemami [Management of ecological and economic systems]. Moscow, Academic book, 1999. $132 \mathrm{P}$.

[19] Ugolnitskiy G.A. Ierarkhicheskoe upravlenie ustoychivym razvitiem [Hierarchical management of sustainable development]. Moscow,Fizmatlit, 2010. 336 P.

[20] Nikonova Ya.I. Upravlenie ekologo-ekonomicheskoy sistemoy subekta Rossiyskoy Federatsii (na primere Kemerovskoy oblasti) [Management of ecological and economic system of the constituent territory of the Russian Federation (by the example of the Kemerovo region): dissertation in support of candidature for an economic degree]. Novosibirsk, 2003. 159 P.

[21] Karas Yu.S. Sotsio-ekologo-ekonomicheskaya sistema kak obekt regionalnogo upravleniya [Socio-ecological-economic system as an object of regional governance: dissertation in support of candidature for an economic degree]. Ufa, 2006. $183 \mathrm{P}$

[22] Zharov A.V. Problemy regionalizatsii sistemy upravleniya prirodopolzovaniem [Problems of a rerional control system of wildlife nanagement]. Ekonomika prirodopolzovaniya [Environmental economics]. 2009. No. 5. P. 27-30.

[23] Gubaydullina T.N. Ustoychivoe razvitie ekologo-ekonomicheskoy sistemy: voprosy teorii i metodologii [Sustainable development of ecological and economic system: issues of theory and methodology]. Kazan, Kuzan University publisher, 2000. 176 P.

[24] Akimova T.A. Teoreticheskie osnovy organizatsii ekologoekonomicheskikh system [Theoretical bases of the organization of ecological and economic systems]. Ekonomika prirodopolzovaniya [Environmental economics]. 2003. No. 4. P. 2-80.

[25] Lukyanchikov N.N., Potravnyy I.M. Ekonomika i organizatsiya prirodopolzovaniya [Environmental economics and organization]. Moscow, YuNITY-DANA, 2010. 687 P.

[26] Modelirovanie i otsenka sostoyaniya medico-ekologo-ekonomicheskikh system [Modelling and assessment of medical-ecological-economic systems]. Baturin V.A, [and others]. Novosibirsk, Publisher of Siberian Branch of the Russian Academy of Sciences, 2005. 249 P.

[27] Stepanov Yu.A., Korchagina T.V., Dmitriev Yu,V. Model upravleniya sostoyaniem ekosistemy pri vozdeystvii tekhnogeneza [Model of the ecosystem state management under the influence of technogenic]. Vestnik kuzbasskogo gosudarstvennogo tehnicheskogo univeristeta [Vestnik of Kuzbass State Technical University]. 2007. No. 6. P. 87-88.

[28] Petrov I.V., Sekistova N.A., Kharkov A.I. Voprosy ekologicheskoy bezopasnosti $\mathrm{v}$ novykh usloviyakh formirovaniya vzaimootnosheniy $\mathrm{v}$ ugolnoy promyshlennosti [The challenges of ecological safety in the conditions of forming the interrelations in coal mining industry]. Gorniy informatsionno-analiticheskiy byulleten [Mining informational and analytical bulletin]. 2009. No. 6. P. 261-263.

[29] Proskura D.V. Modernizatsiya institute ekologicheskogo monitoringa $v$ sisteme ekologo-ekonomicheskoy deyatelnosti ugledobyvayushchey otrasli [Modernization of the institute of ecological monitoring in the system of environmental-economic activity of the coal-mining industry]. TERRA ECONOMICUS [TERRA ECONOMICUS]. 2012. Vol. 10. No. 4. P. 53-55.

[30] Mikhailov V.G., Koryakov A.G., Mikhailov G.S. Environmental risks management in the process of coal mining and processing. Journal of Mining Science. 2015. Volume 51, Issue 5.

[31] Volynkina E.P., Kuznetsov S.N., Pane A.P. Balansovye uravneniya materialnikh potokov syrya, produktsii I otkhodov regionalnoy tekhnoekosistemy [Balance equation of flows of regional technoecosystem raw material, production and waste]. Sbornik dokladov chetvertoy Mezhdunarodnoy nauchno-prakticheskoy konferentsii "Upravlenie otkhodami - osnova vosstanovleniya ekologicheskogo ravnovesiya regionov Rossii" [Proceedings of the Fourth International Scientific and Practical Conference "Waste management - the basis of 
restoring the ecological balance of the regions of Russia"]. Novokuznetsk, Publishing of the SibGIU, 2012. P. $80-89$.

[32] Schastlivcev E.L., Stepanov Yu.A., Korchagina T.V. Vliyanie ugledobychi na formirovanie tekhnogennykh landshaftov [The impact of coal mining on the formation of man-made landscapes]. Vestnik kuzbasskogo gosudarstvennogo tehnicheskogo univeristeta [Vestnik of Kuzbass State Technical University]. 2007. No. 1. P. 78-80.

[33] Te A.A. Formirovanie ekologo-ekonomicheskikh system regionalnogo upravleniya gornodobyvayushchim proizvodstvom [Formation of ecological and economic systems of regional mining management]. Gorniy informatsionno-analiticheskiy byulleten [Mining informational and analytical bulletin]. 2011. No. S4-8. P. 13-21.
[34] Kalabin G.V. Quantitative assessment procedure for environmental conditions in the mining and processing industry areas. Journal of Mining Science. 2012. T. 48. No. 2

[35] Kalabin G.V. Principles of macro-ecological risk mapping of mining industry areas, Journal of Mining Science. 2012. T. 48. No. 6.

[36] Efimov V.I., Sidorov R.V., Korchagina T.V. Obrazovanie otkhodov ot predpriyatiy ugolnoy otrasli na territorii Kemerovskoy oblasti [Generation of coal mining production wastes in the Kemerovo Region territory]. Ugol [Coal]. 2015. No. 12. P. 73-76. 